\title{
Sustainable development of non-profit and non- governmental organizations: financial and organizational mechanisms
}

\author{
Alexander Pyanov ${ }^{1}$, Elena Drannikova ${ }^{2}$, Evgeny Shevchenko ${ }^{3}$, and Zarema Kochkarova ${ }^{4}$ \\ ${ }^{1}$ North-Caucasus Federal University, Pushkin str., 1, Stavropol, 355009, Russian Federation \\ ${ }^{2}$ MIREA-Russian Technological University, Kulakova str, 8 Stavropol, 355035, Russian Federation \\ ${ }^{3}$ Stavropol State Agrarian University, Zootechnicheskiy Ln, Stavropol, 355017, Russian Federation \\ ${ }^{4}$ Stavropol Institute of Cooperation (branch) of BUKEP, Goleneva str., 36, Stavropol, 355035, Russian \\ Federation
}

\begin{abstract}
This article aims at analysing the financial and organizational mechanisms of the third sector, namely the non-profit organisations (NPOs) and non-governmental organisations (NGOs). In addition, it focuses on the sustainable development of non-profit and non-governmental organizations. The paper shows that in order to achieve sustainable development and embark upon the path of the "green economy", NPOs and NGOs need to apply effective financial and organisational mechanisms that would also coincide with their regional priorities and socio-economic objectives that would take into account the environmental specifics and priorities of the given region. The article draws various examples and case studies from various countries and regions around the world to prove its points and provide some guidelines for relevant stakeholders and regulators.
\end{abstract}

\section{Introduction}

Although the sustainability non-profit includes environmental, social, and governance goals, they are not only fundamental to the organization's purpose, but also guide its activities [1]. Each counterpart is unique in that it differs in its mission, mission statement, organizational structure, leadership structure and mission. In addition, there are resources that help one's organization address long-term sustainability and engage sustainability experts to help keep the organization in line with its goals. In the world of profit, poor management and lack of oversight can undermine a non-profit enterprise [2]. If the aim is to create and continue to operate sustainable services for the community, merging businesses with another non-profit organisation providing similar services is a viable strategy. One of the ways an organization can protect itself from bad management is to have a solid business plan that includes performance measures. It is clear that if one has the ability to monitor when her or his organization has gone off track and detect problems early, she or he are in a much better position to fix these problems before they fatally undermine the organization's financial health and programs [3].

\footnotetext{
* Corresponding author: apianov@ncfu.ru
} 
Today's economy can serve as an opportunity to develop creative and sustainable financing mechanisms to revive non-profit institutions. Specifically, it should focus on developing new creative financing mechanisms that help non-profits become more sustainable in the long term, and allow them to focus their resources more on the important programs and services they provide, rather than on themselves [4]. Creative brainstorming is an important part of the search for transformative ways to improve traditional non-profit financing techniques through more sustainable methods. The long list of definitions of nonprofit sustainability is a good source of inspiration for developing sustainable financing mechanisms for non-profit organizations. Sometimes people use non-profit sustainability to mean that non-profits have moved away from private philanthropy and become self-sufficient - with no source of income to earn. Sometimes non-profits arise from an imbalance created by the market, such as a failure to provide education or a lack of access to affordable housing [5].

It is rare for a non-profit to find a way to make markets pay for something they have created. GreenAmerica.org, or social invest Green America, is a non-profit membership organization founded in 1982. Its mission has always been to harness the power of the private sector to create a socially just and environmentally sustainable society for the benefit of all Americans, not just the rich and powerful. It is a professional company, institution and organisation that makes sustainable and responsible investments. Its investment practices take into account environmental, social and corporate governance criteria to achieve the best possible return on investment for its clients and their shareholders. Its investment efficiency has shown us that non-profit organizations can achieve even greater benefits if its sustainability mission is coupled with the introduction of more sustainable operations. The organization found that facility managers are better positioned to achieve operational sustainability goals if they understand the energy, lighting, and water systems [6]. Careful planning and improvements in energy management can lead to a successful greening of the operation. Thence, successful NPOs and NGOs should focus on energy efficiency, energy saving, water and wastewater management and waste management.

Some non-profit organizations attempt to save the endangered species, others help to collect used clothing and shoes to protect the environment and support the sustainable development of impoverished communities around the world. Other non-governmental organizations dedicate their efforts to preserving biodiversity and securing sustainable livelihoods. Thence, the scope of NPOs and NGOs actions is broad and the field of operation is vast. It is therefore desirable that all of them are regulated and united in their mission to create a central authority that can improve and build better communities.

\section{Company efficiency as a system phenomenon}

Systems management theory stipulates that companies and human bodies consist of several components that work together in a large system that can function optimally [7]. According to this theory, the success of an organization depends on its ability to function as a system, not on its individual components. Other elements that are crucial to the success of a company are the departments, working groups and business units, whether in the department, working group or business unit [8]. Managers should be always reminded that most problems are systemic and that it is their responsibility to improve the system so that workers, management and non-management can act more effectively. In practice, managers need to evaluate events within their company to determine the best management approach. High quality leads to high productivity, which in turn leads to long-term competitiveness. In theory, this theory enshrines the idea that companies can stay in business and gain greater market share by providing more and more jobs [9]. The main cause is cost increases and the main cause is incentives. If the hockey stick phenomenon negatively affects a company's 
costs, executives can change incentives to make them more favourable to the company. The obstacle to change would be the bullwhip effect and its negative impact on the company's profits and revenues [10]. If one eliminates the wasting time effect, there is a trade-off - but it is not as bad as it used to be. As can be seen in the literature on the bullwhip effect, price fluctuations are one of the main causes associated with this phenomenon and a way to reduce it. It would be to change pricing policy through various targeted programmes. On the other hand, studies on marketing channels have shown that customer dynamics and behaviour must be taken into account and that trade-offs and promotions can be beneficial for both retailers and wholesalers [11]. Building on the way analytical human resource management (HRM) seeks to locate itself in its larger contexts, the main trend of this analysis is not only in the way it might work, but also in how the model relates to the intervention variables involved (e.g. customer behaviour, pricing, sales, etc.) [12]. One of these stems from the need to demonstrate how human resources can contribute to the viability of businesses and lay the foundations for a sustainable competitive advantage. To create a resource-based view of HRM's role in the business environment, one needs to look at how it helps to create valuable skills and build a barrier against imitation. The second important driver was the belief that in order for HR policies to function well, they must be effectively implemented by superiors, positively improve employee attitudes, promote productive behaviour and promote innovation [13].

The COVID-19 pandemic led many companies to introduce shorter working schedules. Employers are being forced to become more flexible to keep their businesses running during the outbreak, including allowing individuals to work from home - an idea that business leaders dislike [14]. Alternative work schedules do not destroy productivity ethics, managers will be more open to new ways of working. In addition, the agile model has revolutionized the software industry, which is widely known for experimenting with innovative management practices. One strategy that companies pursue is to create smaller, more agile teams and help employees become more productive themselves. Teams are divided into smaller groups, which regularly hold short face-to-face meetings. In short, overstretched employees are seen as a potential threat to the company's long-term success rather than an opportunity for growth. This is similar to Taylorism that involves dismantling components of manual tasks in a manufactured environment and timing the movement so that there may be a proven best way to accomplish this task [15]. Although scientific management techniques are still used to increase productivity and efficiency in both the private and public sectors, they tend to neglect many human aspects of employment. Specialised services could prove useful in this area by improving productivity.

\section{Financial and organizational sustainability}

Planning for the financial and organizational sustainability should include the future strategic objectives and explain how the goals of the organization will affect the needs of more and other resources [16]. The strategic plan of the organization includes a long-term vision for the future of the organization and its goals, as well as the current financial situation. One needs to consider the individual programs and management functions that encompass the company, the organization as a whole, and its relationships with other organizations and stakeholders. Countless studies have been carried out and reports have been produced to support the corporate case for sustainability [17].

Such a consistent outcome should help dispel the notion that sustainability is a burden on a company because of increased communication and operating costs. Transparency and comprehensive sustainability goals are great business skills and support the success of corporate strategies. As corporate sustainability initiatives become increasingly part of core business strategies, executives need to rethink the future of both corporate finance and 
business investment to promote social welfare. The United Nations Global Compact provides the guidance and resources that financial managers need to transform their business models and seize the $\$ 12$ trillion in market opportunities that such a move can open up. This includes access to finance in countries with less developed financial markets with Sustainable Development Goals (SDG) solutions that are more likely to attract portfolio investors [18].

Generally, the role of financial institutions in the development of sustainable financial and sustainability initiatives for businesses is very important. Managers regularly make decisions that cause changes in financial variables and can have a positive or negative impact on financial sustainability. A company's financial structure is usually so complex that shareholders come to conclusions without considering costs, feasibility, and other alternatives. Faced with a fork in the road between using more debt or equity, the optimal point must be found that will allow the company to develop sustainably. Just like the sustainability of a person or family, there are many complex and dynamic dimensions that must also be sustainable in an organization [19].

Just in any organisation, the primary dimension that, if well managed, ensures the sustainability of the organisation is the ability to manage its finances effectively. But even thriving organizations need to manage their finances effectively, not only in terms of financial sustainability, but also in terms of long-term sustainability. This is true and is becoming increasingly important, and the author, a respected non-profit manager and consultant, has developed a framework that helps non-profit leaders adopt an approach that integrates financial performance and social impact into strategic decision-making [20]. The premise of the book is to bring together financial and impact information in an integrated and merged discussion of what is "true" and "increasingly important" about non-profit sustainability and its impact on an organization's long-term sustainability. It contains practical tips and tricks to achieve sustainability of non-profit companies and deal with cuts. Times are tight, especially when it comes to financial management, but also when they are not. Society lacks meaningful stories and relevant indicators to make the right decisions and win public support. While $21^{\text {st }}$ century companies integrate social responsibility and sustainability practices into their business models, $21^{\text {st }}$ century non-profit organizations do not integrate financial considerations [21]. The sustainability gap is closing, but society still lacks a meaningful history and a relevant indicator, both in terms of decision-making and in building and building public support. Sustainability means meeting our current needs without compromising our ability to meet our future needs. Moreover, sustainability means that we can meet current needs without sacrificing our long-term economic and environmental sustainability, without compromising our ability to meet these needs for the future [22].

\section{Financial and organizational mechanisms of non-profit organizations}

For non-profits that want to fund their activities through donations, public confidence depends on the amount of money that non-profits can raise. The activities that non-profit organizations participate in can help to build public confidence in standard ethical practices. Today's public seems more concerned than ever about non-profit institutions that are breaking trust. There are more than 1.5 million registered non-profits in the United States alone, including more than 2.2 million non-profits [23]. To foster trust, which can be so quickly eroded by the bad deeds of a few individuals, organizations must implement strict internal controls and fraud policies coupled with technology and systems to support prevention efforts.

Non-profit organizations are subject to non-distributional restrictions, and any revenue exceeding expenditures must be committed to the purpose of the organization and not be taken over by private parties. The basic principles of good corporate governance apply to 
non-profit-making companies as well as to public for-profit companies. A wide range of organizations are non-profit organizations, including charities, non-profits, foundations and other organizations. Non-profit organizations generally seek government approval to be taxexempt, but some organizations may join as non-profits to secure tax-exempt status. They can also receive tax-deductible contributions from the employer, state, local authority or other government entities, as well as from individuals. Good governance starts with a high-quality board, regardless of the tax status of your organization. Laws allows non-profit organizations and organizations to set out their governance and operational strategies. Once the Articles of Association of a company have been established, the Board of Management and managers must follow the governance or operational guidelines as well as the corporate governance principles set by their board of directors. Members of the non-profit board oversee matters that are critical to the health of their organizations. They oversee and are responsible for the financial and operational management of the organizations and their operations [24]. The boards of directors of a non-profit organisation manage the day-to-day operations and the employees. They are responsible for formulating the main guidelines, policies and strategies for the organization in accordance with the mission and declared purpose of the non-profit organization. In the United States, the legal framework that defines government, business, and non-profit organizations may be less different from country to country. Non-profit organizations are legally exempt from tax by companies in the area of profit-taking through their taxes. They are also called "non-profit organizations, which are also called "collective actions of citizens pursuing mission-oriented goals" and are not founded and organized to make a profit. Internationally, this refers to non-governmental organisations, although the term can also apply to companies that are for-profit.

A non-profit organization exists to provide a particular service or program as stated in its mission, such as education, health care, or education for the poor. The purpose of functional accounting is to represent the cost of services based on the mission of the program and supporting such management, general management and fundraising. This requires non-profit organizations to allocate spending through program management and general fund-raising. When the organisation is subject to an annual audit, it must be presented with every functional area. It then will be obliged to put its opinion into perspective by stating that the statement is not a statement prepared in accordance with generally accepted accounting standards

\section{NPOs and efficiency of social services}

Passing more money to religious and social service groups could put additional service providers in a rapidly changing environment. Many countries are trying to cut costs and encourage innovation by outsourcing programs and functions to for-profit or non-profit service providers. The reduction of government and the improvement of its efficiency offer the possibility of organising new service and delivery systems and thus circumventing the public employee unions. Several other issues that are important for understanding the longterm impact of welfare reform can be identified. Financial strength and high profits crowd out the non-profit organisations that are the most effective public-private partnerships in social security and leave social welfare recipients vulnerable, as market forces later drive companies into other areas [25]. The ability of local governments to manage these contracts is under threat, as private non-profits use up their talent pool. The accountability of vulnerable customers can be ensured by a contract that goes beyond the obligation. There should be a model for identifying and mentoring organisations in the process of promoting public-private partnerships in the field of social security and other social services. A number of non-profit and non-profit organizations' stories reflect some of the insights shared here about the impact of non-profits and their impact on social services worldwide. Since non-profit organizations choose to work together for a variety of reasons, one can find that most non-profit 
organizations increase organizational efficiency, increase organizational effectiveness, and drive a broader transformation of the social system. The result is that these organizations are able to advance their declared missions and shared goals more effectively [26]. Increased organisational efficiency means they are able to do their work faster and with fewer resources. If successfully implemented, this approach allows cooperating organisations to experiment with different solutions to problems in the pursuit of a change in the social system and to position their activities and efforts in relation to and in connection with other actors. For non-profit organizations focused on increasing their effectiveness, many non-profits have chosen collaboration as a way to use their resources and resources to achieve more comprehensive systemic change. Most recently, the market incentives created by the growing popularity of performance-based contracts have spurred innovation and desirable management changes for many non-profit providers. Dramatic changes have occurred in systems that provide employment, training and services to welfare recipients in a political environment that has historically been dominated by both the public and non-profit sectors [27]. This distortion of contractual intentions has led to the motivation of public and private contractors to make decisions to provide services that may jeopardise the well-being of customers in order to minimise costs. Finally, while systems of managed competition in the private sector are improving significantly, many others are in danger of losing their distinctive public service contracts.

\section{Conclusions}

All in all, it appears that for achieving sustainable development and turning to the "green economy", NPOs and NGOs need to apply effective financial and organisational mechanisms that would also coincide with their regional priorities and socio-economic objectives that would also take into account the environmental specifics and priorities of their regions.

In addition, NPOs and NGOs need strict management guidance and steering in order to achieve their sustainable goals and objectives. Quite often, they drift away in their missions and mundane problems failing to deliver efficiency. Here is where contract management might come handy. This form of contract management has many advantages, but managing and safeguarding the performance of large providers also presents new administrative burdens and challenges. The deployment of some large local contractors has created new challenges in competition management. The management of fewer large contracts and the management of prime contractors and their subcontractors has adapted to a growing model that uses large capital projects in government contracts. This form, with a prime contractor and its managed subcontractor, has had to adapt to the growing models used in some of the largest capital projects for government contracts. Many non-profit organisations work by raising money from thousands of donors and allocating it to numerous local agencies. Unlike mutual funds, these charities have traditionally coordinated little with the organizations that receive their money, and rarely commit to multi-year support. Indeed, until recently, one of the largest charities that distributes tens of billions to health and human-health non-profits was unable to name a single improvement that it could link to its donations. Therefore, with a well-balanced guiding system and clear objectives NPOs and NGOs might succeed. This is something that requires assistance and support from stakeholders and policy-makers. They are the ones who appear to play a crucial role in promoting sustainable non-profit organisations.

\section{References}

1. E. Cardillo, M. Longo, Sustainability, 12(9), 3675 (2020) 
2. S. Haeffele, V. Storr, The Review of Austrian Economics, 32(3), 229-249 (2019)

3. L. Ardito, R. Dangelico, Corporate Social Responsibility and Environmental Management, 25(4), 426-440 (2018)

4. S. Ilyas, M. Butt, F. Ashfaq, D. Acquadro Maran, Economies, 8(4), 101(2020)

5. W. Strielkowski, Y. Tumanyan, S. Kalyugina, Economics and Sociology, 9(2), 293-302 (2016)

6. S. Kumar, P. Malegeant, Technovation, 26(10), 1127-1135 (2006)

7. C. Berlin, C. Adams, Production ergonomics: Designing work systems to support optimal human performance (2017)

8. G. Santos, J. Afonseca, N. Lopes, M. Félix, F. Murmura, International Journal of Quality and Service Sciences, 10(3), 214-232 (2018)

9. M. Bowers, J. Hall, M. Srinivasan, Business Horizons, 60(4), 551-563 (2017)

10. R. Kusumaputri, International Journal of Business and Technology Management, 3(1), 21-29 (2021)

11. S. Milberg, A. Cuneo, C. Langlois, Industrial Marketing Management, 76, 192-202 (2019)

12. F. Cooke, Human Resource Management Journal, 28(1), 1-13 (2018)

13. T. Jones, J. Harrison, W. Felps, Academy of Management Review, 43(3), 371-391 (2018)

14. M. Kaushik, N. Guleria, European Journal of Business and Management, 12(15), 1-10 (2020)

15. M. Attaran, S. Attaran, D. Kirkland, International Journal of Enterprise Information Systems (IJEIS), 15(1), 1-23 (2019)

16. A. Bastas, K. Liyanage, Sustainable Production and Consumption, 17, 11-30 (2019)

17. A. Batista, A. Francisco, Sustainability, 10(1), 226 (2018)

18. W. Qi, Z. Shen, Production and Operations Management, 28(2), 393-406 (2019)

19. F. Rosati, L. Faria, Journal of Cleaner Production, 215, 1312-1326 (2019)

20. N. Gali, T. Niemand, E. Shaw, M. Hughes, S. Kraus, A. Brem, Technological Forecasting and Social Change, 160, 120230 (2020)

21. G. Nigri, M. Del Baldo, Sustainability, 10(12), 4499 (2018)

22. A. Verma, International Journal on Environmental Sciences, 10(1), 1-5 (2019)

23. D. O'Brien, M. Craig, Building Smart Nonprofits: A Roadmap for Mission Success (2020)

24. M. Golensky, M. Hager, Strategic leadership and management in nonprofit organizations: Theory and practice (2020)

25. V. Druzhynina, G. Likhonosova, G. Lutsenko, Marketing and Management of Innovations, 2, 54-68 (2018)

26. P. Benevene, L. Dal Corso, A. De Carlo, A. Falco, F. Carluccio, M. Vecina, Frontiers in Psychology, 9, 2069 (2018)

27. I. Ferguson, V. Ioakimidis, M. Lavalette, Global social work in a political context: Radical perspectives (2018) 